\title{
Calcitonin: characterisation and expression in a teleost fish, Fugu rubripes
}

\author{
M S Clark, L Bendell', D M Power², S Warner, G Elgar and P M Ingleton' \\ Fugu Genomics Group, MRC-HGMP Resource Centre, Genome Campus, Hinxton, Cambridge, UK \\ ${ }^{1}$ Division of Genomic Medicine, Institute of Endocrinology, University of Sheffield, Beech Hill Road, Sheffield S10 2RX, UK \\ ${ }^{2}$ CCMAR, Centre of Marine Sciences, Universidade do Algarve, Campus de Gambelas, 8000-810 Faro, Portugal \\ (Requests for offprints should be addressed to M S Clark; Email: mclark@hgmp.mrc.ac.uk)
}

\begin{abstract}
The present report describes the structure and expression of the calcitonin gene in Fugu rubripes. It is composed of 4 exons and 3 introns. Splicing of exons 1, 2 and 3 generates the calcitonin pre-proprotein, while splicing of exons 1,2 and 4 generates calcitonin gene-related protein (CGRP). Exons 1 and 2 encoding the signal sequence and the $\mathrm{N}$-terminal peptide are common in both the gene products and this gene organisation has been conserved in human, rat, chicken and salmon. The gene environment around calcitonin in Fugu has been poorly conserved when compared with human, apart from a small gene cluster. The calcitonin gene in Fugu has a widespread tissue distribution but it is most highly expressed in the brain. The abundance of gene expression in the ultimobranchial gland and the pituitary indicates that these are important sites of production and that the peptide is probably secreted into the circulation and/or acts as a paracrine or autocrine controlling factor. Whilst the function of calcitonin in fish is still largely unknown, the distribution described here suggests that one of the potential functions may be as a neuropeptide.
\end{abstract}

Journal of Molecular Endocrinology (2002) 28, 111-123

\section{Introduction}

Calcitonin and its gene in fishes are of particular interest because of the phylogenetic position of fishes both as early vertebrates and as aquatic species. Calcitonin in mammals and birds is acknowledged to be the principal hypocalcaemic agent, but the situation in fishes is less clear and a role for calcitonin in calcium regulation may be subordinate to other functions which include acting as a neurotransmitter. Control of calcium homeostasis in fish is different from that in terrestrial vertebrates because the aquatic environment, particularly sea water, provides a more-thanadequate supply of calcium so that mechanisms of internal calcium mobilisation and deposition, in which calcitonin is an important factor for tetrapods, are less essential and less well developed. Indeed fish do not have a parathyroid gland and endogenous parathyroid hormone (PTH) has not been detected in fish. PTH is the principal hypercalcaemic factor of higher vertebrates, suggesting that the tetrapod system involving calcium mobilisation by $\mathrm{PTH}$ and reduction in circulating calcium by calcitonin only evolved with adoption of terrestrial life. Moreover, fish have other hypocalcaemic factors including stanniocalcin from the corpuscles of Stannius (Butkus et al. 1987), although calcitonin can act as an inhibitor of calcium transport in fish gills (Milhaud et al. 1977, Wagner et al. 1997). The evolutionary history and functions of calcitonin in aquatic vertebrates, therefore, require further investigation and as part of ongoing studies into the endocrine/paracrine factors involved in calcium homeostasis in marine fishes we have sequenced the gene for calcitonin from the puffer fish Fugu (Fugu rubripes). Fugu has a compact genome of $400 \mathrm{Mb}$ and has been proposed as a fish model genome (Brenner et al. 1993). The ability to search large amounts of sequence scan data (http://www.fugu.hgmp.mrc. ac.uk) and to identify known gene fragments, in this particular case those putatively involved in calcium regulation, makes Fugu an attractive species for 
genomic studies. These sequence scan fragments provide excellent fish-specific probes with which to isolate and characterise the entire gene. Calcitonin has been cloned from Fugu, its genomic organisation determined and gene expression demonstrated in tissues by in situ hybridisation and RT-PGR.

\section{Materials and methods}

\section{Identification and isolation of calcitonin gene}

During routine Fugu cosmid library sequence scanning, 6 cosmids (C022A11, G105K06, G133 L12, C135F24, C135H05, G194K01) were identified as having a gene fragment with high sequence similarity to human calcitonin (probability value in excess of $\left.1 \mathrm{e}^{-05}\right)$. Sequence scanning was performed as described in (http://www.fugu.hgmp.mrc.ac.uk/ ISO900/BIOLOGY/FUGU/fugu.shtml) and gene content identified by searching the individual sequence fragments using BLAST v2.0 (Altschul et al. 1997) against the SPTR (Bairoch \& Apweiler 2000) and Unigene databases (http://www. ncbi.nlm.nih.gov/Unigene/Hs.home.html). Confirmation of the overlapping nature of these cosmids was confirmed by analysis of their SacI restriction enzyme digestion patterns and short-range linkage gene content. The size of the calcitonin $11 \mathrm{p}$ contig was determined by analysis of SacI restriction enzyme digest patterns of the 5 cosmids (C133 L12 was identified as a co-ligation) using the Alpha Imager 1220 v5.5 (Alpha Innotech Corp, USA). Calcitonin positive sequence fragments from all 6 cosmids were transferred to a UNIX environment and quality clipped using a modified Pregap script (Bonfield \& Staden. 1996). Sequences were screened against sequencing and cloning (pBluescript and Lawrist4) vectors and matching regions were masked prior to further analysis. Passed sequences were then assembled using Gap4 (Bonfield et al. 1995). Contiguation and finishing of the gene was performed using PCR walks. Analysis of the finished sequence was carried out using the HGMP Nix interface (G Williams, P Woollard and P Hingamp, unpublished data; http://www.hgmp. mrc.ac.uk/NIX/). The calcitonin gene was submitted to the EMBL database with the accession number AJ289717. The sequence fragments from the 6 cosmids were submitted to EMBL as GSS fragments with the accession numbers AL626822 to AL627067 inclusively. Comparative human gene map positions were determined using the ensembl viewer (v1.0.0) (http://www.ensembl.org/) and gene names assigned using the HUGO nomenclature accessed via the ensembl link to LocusLink (http://www.ncbi.nlm.nih.gov/LocusLink/). Multiple sequence alignments were carried out using Clustal X (Higgins et al. 1991) and displayed in Boxshade (http://www.isrec.isb-sib.ch/ software/BOX_form.html). Percentage identity and similarity scores were produced using the needle programme from the EMBOSS suite of programmes (http://www.uk.embnet.org/Software/ EMBOSS/Apps/) with a Gap opening penalty of $10 \cdot 0$ and a Gap extension penalty of $0 \cdot 5$.

\section{Phylogenetic analysis}

Calcitonin genes in the databases are in a mixture of formats, both DNA and protein. Only 9 (including Fugu) comprise the whole translated peptide, more are present as mature peptide sequences only, whilst a further 29 are available as mature peptide nucleotide data in Suzuki et al. (1999). Phylogenetic analysis was carried out with the mature peptide, as the assumption was made that evolutionary pressure is strongest on the biologically active portion of the gene. The latter is only 32 amino acids long and cursory analysis of the amino acid sequence in fish shows that many of the nucleotide substitutions are silent (data not shown), as they do not alter the amino acid sequence of the translated protein. Analysis of DNA sequences in this case was considered to represent the most accurate method of defining evolutionary relationships. Phylogenetic analysis was carried out from the Clustal X multiple alignment output using both the Neighbour Joining method (Saitou \& Nei 1987) via the PHYLO_WIN interface vl.2 (Galtier et al. 1996) and the Maximum Likelihood method (Felsenstein 1981) via Phylip v3.57c. Multiple alignment parameters for PHYLO_WIN were: Gap opening 15; Gap extension 0.05; Delay divergent sequences 40\%; DNA transition weight $0 \cdot 50$, with 5000 bootstrap replicates. Maximum Likelihood analysis was carried out using the dnaml programme with default parameters and global rearrangements. The phylogenetic output was displayed using Treetool (Olsen et al. 1992). 


\section{RT-PCR of gene expression in Fugu tissues}

mRNA was isolated from ten tissues: liver, heart, kidney, spleen, gonads, eye, brain, gut, spinal cord and gill using the RNeasy kit from Qiagen and post-treated with DnaseI to remove contaminating DNA (Ausbel et al. 1991). RT-PCRs were performed on first strand synthesis mRNA transcribed using the Promega Reverse Transcriptase System primed with oligo dT. To ensure that equal quantities of the transcribed RNA were included in the PGR reactions for calcitonin detection, initial PCRs were run using Fugu-specific actin primers designed from the data of Venkatesh et al. (1996). The primers crossed two exons and so any genomic contamination would have been detected by the presence of multiple products. RT-PCR reactions for calcitonin were performed using a primer pair (forward 5' cctacgccetggtcatttg $3^{\prime}$; reverse $5^{\prime}$ cagctcctgggacagtttg $3^{\prime}$ ) designed to be specific for calcitonin. The forward primer was located in Fugu exon 1 (common for both calcitonin and calcitonin gene-related protein (CGRP)), whilst the reverse primer was located in Fugu exon 3 (specific for calcitonin). PCR conditions for both the actin and calcitonin primers were as follows: an initial denaturation stage of $95^{\circ} \mathrm{C}$ for 3 min followed by 35 cycles of $95^{\circ} \mathrm{C}$ for $20 \mathrm{~s}, 60^{\circ} \mathrm{C}$ for $20 \mathrm{~s}, 72^{\circ} \mathrm{C}$ for $40 \mathrm{~s}$ and a final elongation stage of $72{ }^{\circ} \mathrm{C}$ for $5 \mathrm{~min}$. All PCR products were confirmed by sequencing.

\section{In situ hybridisation}

Calcitonin gene expression was demonstrated in puffer fish tissues using digoxygenin (DIG)-labelled oligonucleotide probes as previously described (Flanagan et al. 2000). Briefly, tissues were fixed in sublimated Bouin-Hollande (Kraicer et al. 1967), dehydrated through graded alcohols, cleared and embedded in wax; sections were cut at $4 \mu \mathrm{m}$ and mounted on APES-coated slides.

Oligonucleotide probes (30-mers) were chosen from the calcitonin-specific sequence of the gene and end labelled with DIG as described in Flanagan et al. (2000) using terminal transferase in a $20-\mu \mathrm{l}$ reaction volume. The sequences chosen were ccc cta acc aag cgt tgc tcc aac ctg agc coding for amino acids 78-87 of the pre-propeptide which includes the first 5 amino acids for the mature peptide and ggc aaa ctg tcc cag gag ctg cac aag ctg, coding for amino acids $10-19$ of the mature peptide. These primers were checked for specificity using the BLAST v2.0 database (Altschul et al. 1997).

In situ hybridisation was carried out as previously described (Flanagan et al. 2000), sections were rehydrated, followed by prehybridisation in deionised formamide and hybridisation with labelled probe at room temperature overnight. A poly $\mathrm{T}$ probe was used as positive control and negative reactions omitted the specific probe or used a sense probe. Hybridisation was detected by incubation with antiserum to DIG/AP-conjugate and colour developed by reaction in a solution of NBT/BCIP and levamisole. Sections were finally mounted in glycerogel.

\section{Results}

The mammalian and chicken calcitonin genes (Rosenfeld et al. 1981, Jonas et al. 1985, Minivielle et al. 1987) are comprised of 6 exons, which via complex alternate splicing of common and unique exons form both the peptides calcitonin (the hypocalcaemic hormone) and CGRP (the neuropeptide) (Amara et al. 1982). The Fugu calcitonin gene has a similar structure, although it was not possible to identify the outermost $5^{\prime}$ and $3^{\prime}$ non-coding exons due to divergence of sequence between Fugu and mammals and the corresponding lack of cDNA sequence (Fig. 1). However, of the 4 exons identified, the intron/exon boundaries and boundary classes have been conserved in mammals. The Fugu gene also undergoes complex alternative splicing to form calcitonin and CGRP. So far, only one calcitonin gene has been identified in Fugu compared with two in human (one of which is a pseudogene) and four in salmon (Lasmoles et al. 1985, Jansz et al. 1996). A Clustal X alignment of the translated Fugu sequence and other fulllength calcitonin protein sequences available in the database (Fig. 2) reveals very little overall conservation of protein sequence; Fugu and human only share $48 \cdot 23 \%$ overall identity. Even within the mature peptide, the overall percentage identity between Fugu and human is still only $53 \cdot 12 \%$, rising to $71 \cdot 88 \%$ when similarity is considered, with only 8 of the 32 amino acids absolutely conserved. These invariant amino acids are located at positions 1, 4, 5, 6, 7, 28 and 32. However, the percentage identity between amino acids of the 


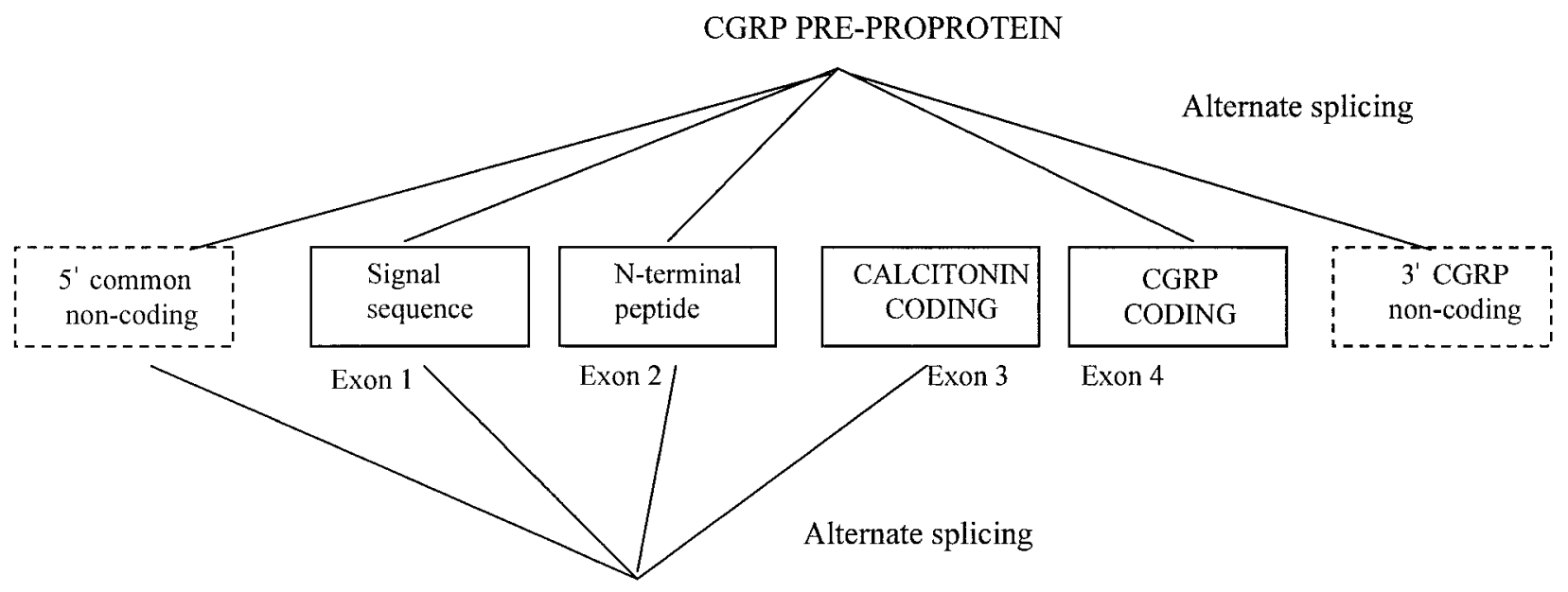

\section{CALCITONIN PRE-PROPROTEIN}



Figure 1 Structure of the calcitonin/calcitonin gene-related protein (CGRP) showing common exons, alternative splicing and post-translational processing. The two terminal exons depicted by dashed lines have been shown to be present in mammals using cDNA sequencing. Because of the lack of homology between these exons in mammals and Fugu, they were not detected in the Fugu genomic sequence. Hence the numbering of the Fugu exons is shown below the solid boxes.

various fish species is much higher. Fugu and chum salmon show an overall identity score of $81 \cdot 62 \%$ for the pre-proprotein which rises to $90 \cdot 62 \%$ (96.88\% similarity) in the case of the mature peptide. Within the fish species for which there is sequence data, 24 of the 32 amino acids of the mature peptide are identical.

Phylogenetic analysis using both the Neighbour Joining and Maximum Likelihood methods produced similar results, of which the latter are displayed in Fig. 3. The stingray formed an outgroup, as would be expected from a species with a cartilaginous skeleton when clustered with other vertebrates with calcified skeletons. The lungfish also occupied a basal position in the phylogram the evolutionary origins of this species are unclear, but it would appear to be more similar to the tetrapods than other fish species. The primitive fish (sturgeon, bichir and gar) formed an ill-defined basal grouping leading to the mammalian and teleost lineages (which included the Fugu calcitonin).
The chicken and reptiles formed a separate lineage, which branched off prior to the mammals and teleosts. Within the teleosts, the eels branched off early, in common with their predicted evolutionary position as Elopomorpha, but apart from the Salmonids, which formed a tight grouping, there is no distinct pattern to the calcitonin relationships of the rest of the fish species. Interestingly, sardine (which also belongs to the Elopomorpha) clustered with the Tetraodontidae (Fugu and the Komon puffer fish). The Neighbour Joining method produced the same groupings, but with the mammals branching off the rest of the species in the tree. However, bootstrap values, even with 5000 replicates, were very low, with figures below 30 present on at least $50 \%$ of the nodes, indicating that a cautious approach should be taken to phylogram interpretation.

Comparison of the Fugu gene data with that of human (Fig. 4) revealed conserved linkage of 4 genes from human chromosomal region 11 p15. 


Sheep
Dog
Mouse
Rat
Human
Horse
Salmon
Fugu
Chicken
consensus

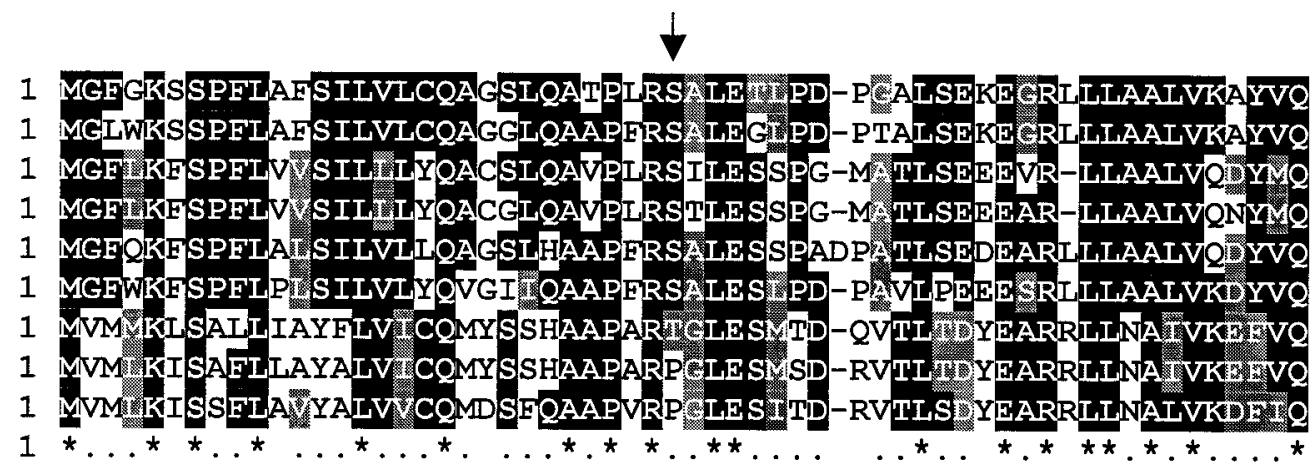

Mature Peptide

Sheep
Dog
Mouse
Rat
Human
Horse
Salmon
Fugu
Chicken
consensus

60 RKTNELEQEE EQEETEDSSIDSSRAKRCSNLSTCVLSAYWKDLNN WR YISGMGEGPETPE 60 RK-NELEQEQEQE-TEGSSLDSSR XKRCSNLSTCVLGTYSKDLNNFHTESGIGFGAETPG 59 MKARELEQEEEQE-AEGSSLDSPRSKRCGNLSTCYिLGTYTQDLNKFHTFPQTSTGVEAPG 59 MKVRELEQEEEQE-AEGSSLDSPRSKRCGNLSTCMLGTYMQDLNKFHTFPQTST GVGAPG 61 MKASELEO-DQE-REGSSLDSPRSKRCGNLSTCMLGTY\%QDENKFHTFPQTARGVGAPG 60 MKVRALEO-DQE-TGG/SLDSPRAKKRCSNLSTCVLGTYUQDLNKFHTFPQTALCVEAPG 60 MTSEELEO-- EAN--EGNSLDRPMSKRCSNLSTCVLGKL SO FLLHKLQTYPRTNGSGTPE

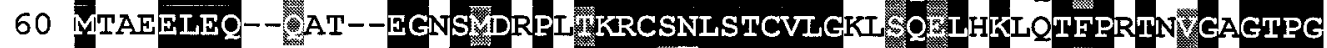
60 MTAEELEQ--AS--EGNSLDRPISKRC NLSTCVLGKLSQSLHKLQTPPRTDVGAGTPG

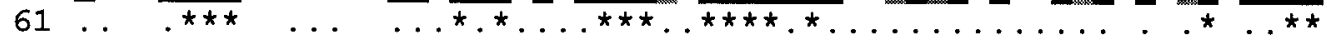

\begin{tabular}{|c|c|c|}
\hline Sheep & 120 & KKRDTANSLETSLSSHIEVPTDAN \\
\hline Dog & 118 & --ー-ー-ー- \\
\hline Mouse & 118 & --- \\
\hline Rat & 118 & --- \\
\hline Human & 118 & KKRDMSSDLERBRRRPHSMPQNAN \\
\hline Horse & 117 & BDIGPHIGTSQDAY \\
\hline Salmon & 116 & DSYDGI \\
\hline Fugu & 116 & YAS CETFGRI \\
\hline Chicken & 115 & 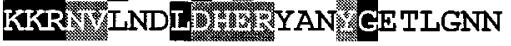 \\
\hline consensus & 121 & \\
\hline
\end{tabular}

Figure 2 Clustal $X$ alignment of the whole calcitonin gene. Arrows indicate the exon/intron boundaries and the mature peptide cleaved at (KR......GKKR) is denoted by the solid line above the sequence in exon 3. SPTR accession numbers of species used in the Clustal $X$ alignment: sheep (P01261), dog (Q9MYV2), mouse (P70160), rat (P01257), human (P01258), horse (Q9N0V5), salmon (P01263) and chicken (P07660).

There were a considerable number of genes from this region in human that were not present in Fugu and there is potentially an evolutionary breakpoint on either side of this linked cluster.

RT-PCR experiments demonstrated that calcitonin was detected very faintly in all tissues studied, but most strongly in the brain $>$ spinal $\operatorname{cord}=$ gill $>$ gut $=$ eye $>$ liver $=$ heart $=$ kidney $=$ spleen $=$ gonads
(Fig. 5). The identification of the brain as the major site of expression mirrors the results of the in situ hybridisation.

The results of in situ hybridisation are shown in Figs 6 and 7. The ultimobranchial gland is a lobed organ composed almost entirely of epithelial cells in which there was abundant calcitonin gene expression (Fig. 6A). Inter-renal cells of the kidney 


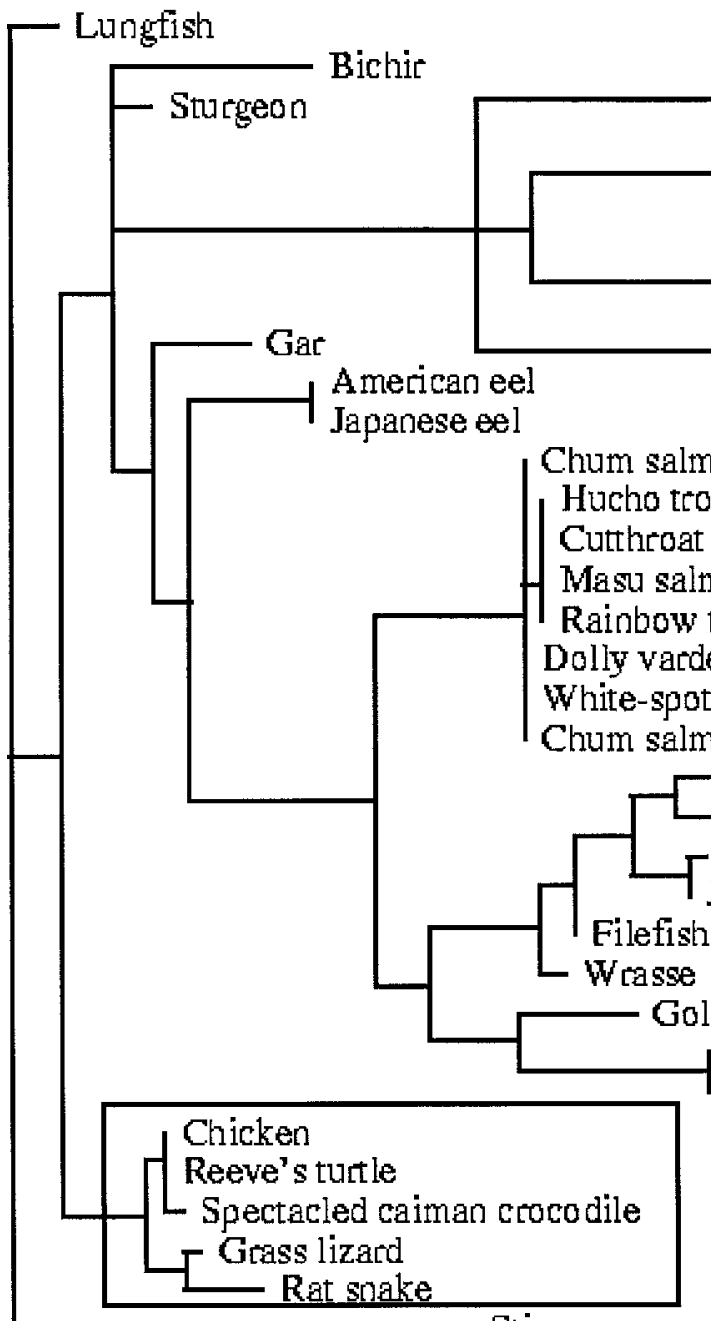

Stingray

Reptiles and Aves

Figure 3 Phylogenetic analysis of calcitonin sequences. Particular groupings (mammals, teleosts, reptiles and Aves) are emphasised by boxed regions. All the data were taken from either Yoshida et al. (1997) or Suzuki et al. (1999) except mouse (X97991), rat (M26137), salmon isoform b (Y00765), dog (X56994), sheep (M98053) and human (X00356). Organisms' common names have been used, the latin names of each species are: lungfish (Protopterus annectens); bichir (Polypterus senegalus); sturgeon (Acipenser dapryanus); gar (Leisosteus oculatus); Reeve's turtle (Geoclemys reevesii); grass lizard (Takydromus tachydromoides); rat snake (Elaphe climacophora); spectacled caiman crocodile (Caiman crocodilus), chicken (Gallus gallus); chum salmon (Oncorhynchus keta); masu salmon (Oncorhynchus masou masou); cutthroat salmon (Salmo clarki); rainbow trout (Onchorynchus mykiss); white spotted char (Salvelinus leucomaenis leucomaenis); hucho trout (Hucho perry); dolly varden (Salvelinus malma malma); Japanese eel (Anguilla japonica); American eel (Anguilla rostrata); goldfish (Carassius auratus); sardine (Sardinops melanosticus); sole (Limanda yokohamae); surffish (Ditrema temmincki); Komon puffer fish (Takifugu poecilonotus); anglerfish (Lophius litulon); wrasse (Halichoeres tenuispinis) and filefish (Stephanolepis cirrhifer). Distance $=.10$.

contained high concentrations of calcitonin mRNA whilst the kidney tubule epithelial cells showed no hybridisation (Fig. 6B). There was also abundant expression in supra-medullary neurones forming the central autonomic nucleus in the brain stem/spinal cord junction, in the dense nuclear 
HUMAN

$11 p$

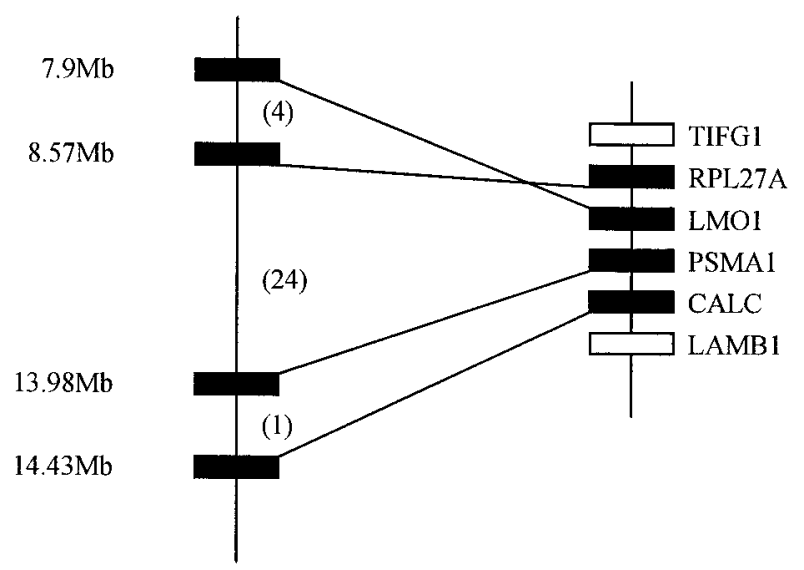

Figure 4 Comparative data map in Fugu and human. The Fugu contig was $52 \mathrm{~kb}$ and showed conserved linkage of 4 human 11p genes RPL27a (60S ribosomal protein), LMO1 (Rhombotin); PSMA1 (Proteasome subunit C2) and CALC (calcitonin). The surrounding genes TIFG1 (Transcriptional intermediary factor $1 \gamma$ ) and LAMB1 (laminin) are found elsewhere in the human genome (1p13.1 and 7q22 respectively) and potentially indicate an evolutionary breakpoint.

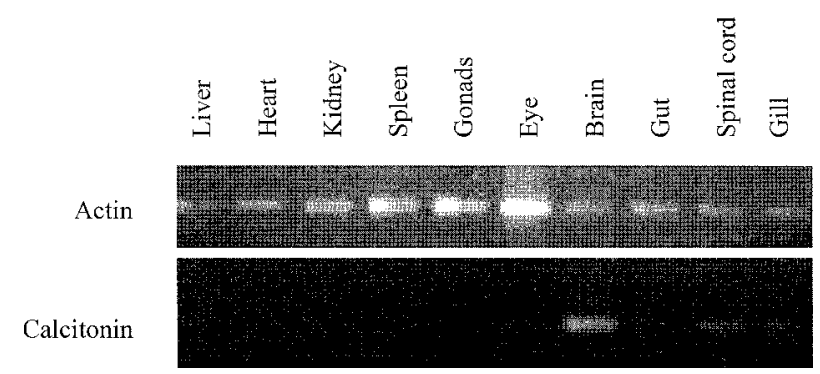

Figure 5 Calcitonin RT-PCR results for ten tissues with the actin control shown above.

region of the mid-brain tectum (Fig. 6C) and in cytoplasm of the ova (Fig. 6E). Some coronet cells of the saccus vasculosus also hybridised with the oligonucleotide probe (Fig. 6F) as well as chloride cells of the gill and the epidermis of the branchial arches but not the branchial respiratory epithelium (not shown). There were high levels of gene expression in the pituitary epithelial cells with the most abundant expression in the growth hormone secreting cells. Figure 7A shows the proximal pars distalis with calcitonin gene expression and immunoreactive growth hormone (Fig. 7B) detected with antiserum to chum salmon growth hormone. There was no hybridisation with sense probes, and negative controls omitting the probe also produced no reactions (Fig. 6D).

\section{Discussion}

The calcitonin gene encodes two bioactive peptides each contained on a separate exon and sharing considerable sequence similarity. This situation is very similar to that found in the pituitary adenylate cyclase-activating polypeptide (PACAP)/glucagon superfamily, the members of which have been proposed to have evolved by exon duplication (Sherwood et al. 2000). It is tempting to speculate that the calcitonin gene may have evolved in a similar manner, particularly as the first two exons are shared and alternative splicing gives rise to either calcitonin or GGRP. Clearly, data is required from species evolved prior to the vertebrates in order that the evolution of calcitonin may be studied in greater detail. Very little information is available about processing of the calcitonin pre-propeptide or about its potential function; whether the pre-propeptide region is important for conformation or has an independent biological activity remains to be shown. The mature peptide is flanked by classic dibasic amino acid processing sites. In the mature peptide, LysK is necessary for the complete expression of biological activity, amino acids 8 to 17 form an amphiphilic alpha helix and form the 3D structure, and the receptor binding region is located between amino acids 24 and 32 (Inoue et al. 1991). Comparison of the gene sequence between all species reveals 7 invariant amino acids at positions 1, 4, 5, 6, 7, 28 and 32. Amino acids 1 and 7 are cysteines which form a disulphide bond and the terminal amino acid is always an amidated proline.

The phylogenetic relationships of calcitonin genes from different organisms would appear to be complex. These have previously been classified into 5 different lineages according to amino acid sequence similarities. These are the human (human, rabbit, rat), pig (pig, cattle, dog and sheep), bony fish (salmon, eel, goldfish, sardine and chicken), cartilaginous fish (stingray) and amphibian (bullfrog) lineages (Takei et al. 1991, Yoshida et al. 1997). In the calcitonin tree, the mammals and reptiles/birds branch at similar 

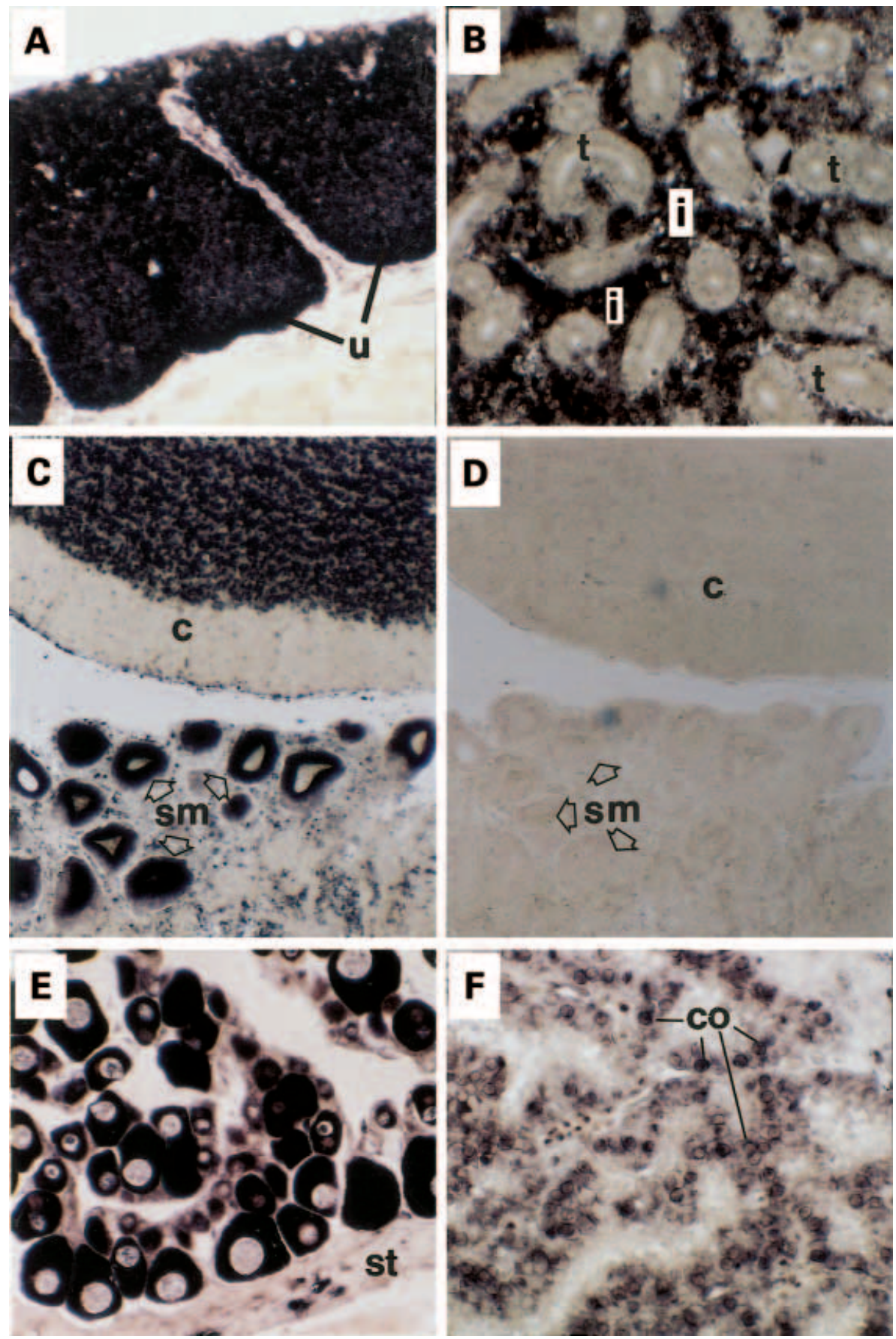

Figure 6 In situ hybridisation using the digoxygenin detection method of calcitonin gene expression in tissue sections of Fugu rubripes. (A) The ultimobranchial tissue showing abundant gene expression in the epithelial cells (u) but none in the adjacent stromal tissue. (B) Kidney tissue in which the tubule epithelial cells ( $\mathrm{t}$ ) did not hybridise with the calcitonin oligoprobe but there was considerable hybridisation in cells of the inter-renal tissue (i). (C) Part of the cerebellum of the brain (c) showing abundant hybridisation in the dense neuronal layer and in supramedullary cells of the spinal cord (sm, arrow heads). (D) A negative control hybridisation reaction using a sense probe in the section of brain and spinal cord adjacent to that in (D). (E) There was abundant calcitonin hybridisation in the cytoplasm of ova but not in the stromal cells (st) of the ovary. (F) Section through the saccus vasculosus showing hybridisation in some of the coronet cells (co). 

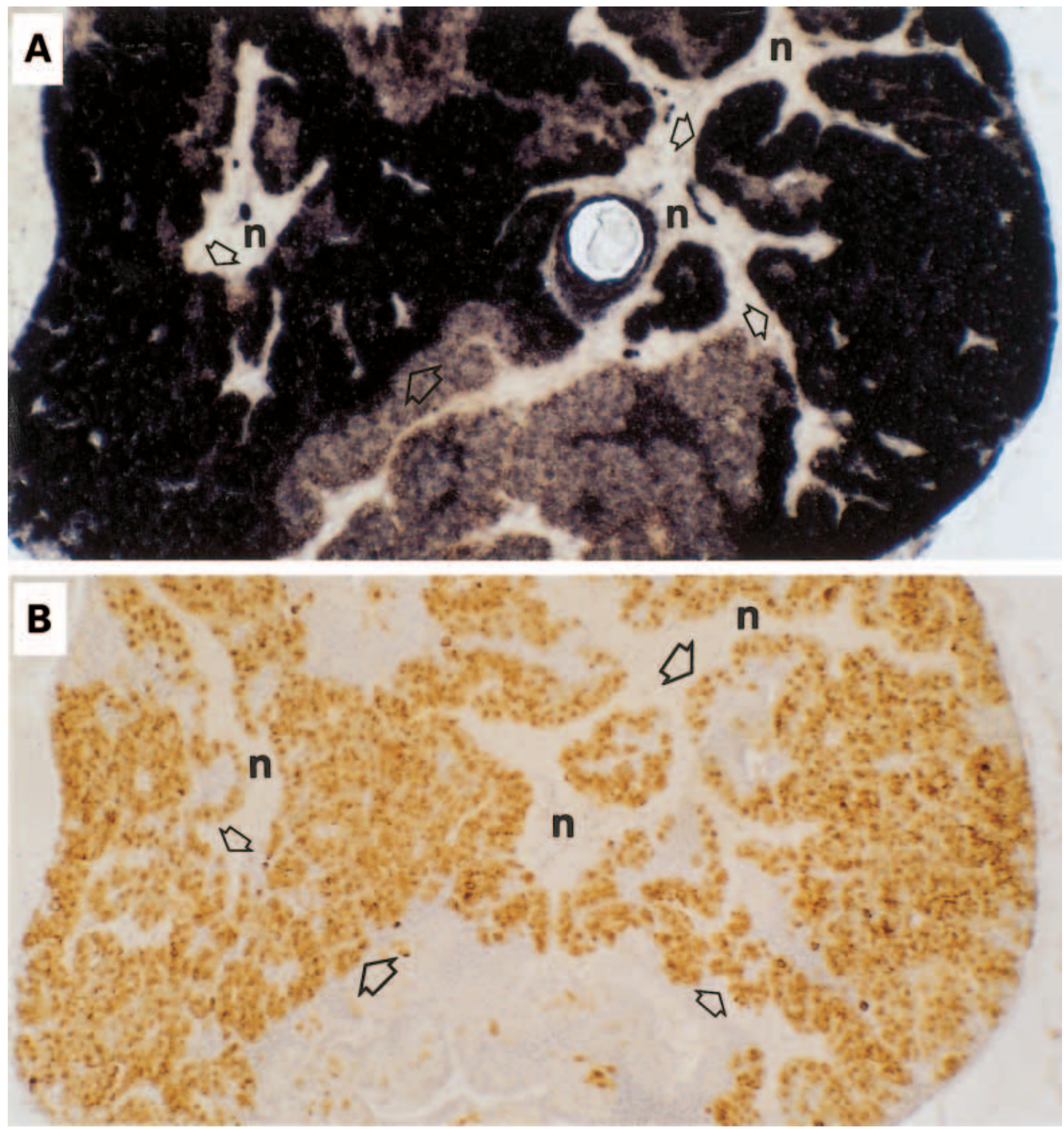

Figure 7 In situ hybridisation of calcitonin gene expression in parasagittal sections of Fugu pituitary. (A) A strong hybridisation signal is evident in secretory cells (open arrows) but no reaction in the nerve axons of the neurohypophysis (n). (B) Immunocytochemistry of a nearby section showing somatotrophs (open arrows) reacting with antiserum to chum salmon growth hormone; $(n)$ marks regions of the neurohypophysis.

times but into distinct lineages, with the teleosts branching off later with the primitive fishes basal to the whole grouping. These results are in agreement with Suzuki et al. (1999), who deduced the inter-relationships using sequence similarity calculations. However, the phylogenetic tree demonstrates far more clearly the inter-relationships between the calcitonin genes of different species, 
and the designation of five separate lineages (Yoshida et al. 1997) therefore requires further evaluation. The evolution of calcitonin is complex with at least three lineages within the fish alone (represented by the eels, salmonids and puffer fish). Whether these computer-derived groupings relate to subtle differences in function between fish species is as yet unknown. Taking a more global approach with the three main lineages of mammals, teleosts and reptiles, different evolutionary forces seem to have been acting on these three groups to produce specialised calcitonins adapted to particular lifestyles. For example, although the reptiles can perform calcium regulation of the terrestrial type, their calcitonin molecules are not intermediate phylogenetically between amphibians and birds. This may be a reflection of their similar breeding strategies which involve production of calcified eggs. Evidence suggests that the biological activity of calcitonin is higher in avian and reptilian hatchlings compared with adults (Taylor et al. 1975, Dacke 1979, Uchiyama et al. 1981); however, the physiological role of calcitonin in adults is still unclear in these species. Teleosts also appear to have developed a more specialised form of calcitonin which may be commensurate with their aquatic lifestyle. However, this piscine ligand can still be recognised by other species such that salmon calcitonin is an effective therapeutic agent in treating loss of calcium from bone in humans (Wisneski 1990).

Although there is a small cluster of genes in Fugu, which map to human chromosomal region $11 \mathrm{p} 15$, which represents a conserved linkage, many genes are present in human which are not present within this region in Fugu. This result is not entirely surprising. There is increasing evidence to suggest that although there are large tracts of conserved linkage between fish and human, gene order is considerably rearranged (Postlethwait et al. 2000, Bouchireb et al. 2001) by a series of inversions. Certainly, consideration of the function of this cluster of genes reveals no common functionality or involvement in a common biochemical pathway which could explain why a particular combination has been conserved except by chance. A further examination of the human gene map reveals that PTH, the major hypercalcaemic agent in tetrapods, is found in the region between LMO1 and PSMA1, which has 24 'missing' genes in Fugu. There is debate as to whether PTH actually exists in fish and the results of linkage analysis clearly show that positional cloning failed to solve this question. It may be that a related hormone parathyroid hormone-related protein (PTHrP), recently isolated from Fugu (Power et al. 2000) and sea bream (Flanagan et al. 2000), is the hypercalcaemic factor in fish (Guerreiro et al. 2001) but clearly more work is needed to resolve this question.

The tissue distribution of calcitonin determined by RT-PGR was in general agreement with the results of in situ hybridisation experiments. The latter method, however, produced a much more precise cell and tissue localisation. The abundant expression of calcitonin mRNA in the ultimobranchial gland indicates that this tissue is an important site of production of the peptide in Fugu and that it is probably secreted into the circulation. To date, we have no measurements of plasma calcitonin in puffer fish but in the rainbow trout, for example, circulating and ultimobranchial levels of calcitonin vary during the annual cycle and in relation to the reproductive cycle (Bjornsson et al. 1987, Foucheron-Peron et al. 1990). However, the expression of the gene in neurones of the central and autonomic nervous systems indicate that it is likely to be an important neuropeptide. Calcitonin in Fugu is found in the supermedullary neurones (Fig. 6C) and in a related puffer fish (Takifugu niphobles) these project processes (axons) into several nerves including the trigeminal, vagus and spinal accessories (Funakoshi et al. 1995). Other evidence suggests that these neurones may have synaptic connections with the central nervous system (Funakoshi et al. 1996) and also with the skin, possibly being involved in chromatophore control. A salmon-like calcitonin has also been described in rat and human central nervous systems (Barlet et al. 1998). The evidence of calcitonin gene expression in cytoplasm of the ova (Buznikov 1984) may suggest it is important for the initial stages of larval development, and elucidation of its function requires further investigation.

The abundance of calcitonin mRNA in Fugu pituitary suggests that it may be secreted into the circulation and/or act as a paracrine or autocrine controlling factor within the pituitary. A pituitary calcitonin-like peptide (pit-CT) has been purified from rat pituitary (Hilton et al. 1998) and subsequent studies showed that the inhibitory effect of pit-CT on secretion of prolactin could be prevented by addition of antiserum to salmon 
calcitonin (Shah et al. 1999), suggesting that the endogenous rat pit-CT was similar to the fish peptide. The cells of origin of calcitonin in rat pituitary have not been specified but in Fugu pituitary, gene expression was demonstrated in cells in both the pars distalis and pars intermedia, with the most abundant expression in the proximal pars distalis which was composed almost exclusively of growth hormone secreting cells. Therefore, these cells would appear to secrete both calcitonin and growth hormone. In the pituitaries examined only isolated cells in the proximal pars distalis reacted with antiserum to sea bream gonadotrophin, indicating that this population of cells was not developed or was not active. Salmon calcitonin has been shown to inhibit gonadotrophin releasing hormone-stimulated release of luteinising hormone by female rat pituitaries (Tsai et al. 1999), so that this effect as well as the inhibition of prolactin cell proliferation (Shah et al. 1999) suggests that intrapituitary calcitonin may modulate both pituitary cell hyperplasia and differentiated function.

The expression of calcitonin gene and detection of the peptide have been reported in gills of the pink salmon (Oncorhynchus gorbuscha) (Martial et al. 1994), but the same authors also reported that gills of the related salmonid, the rainbow trout (Salmo gairdneri) did not contain calcitonin (FouchereauPeron et al. 1990). They suggest this could be due to the fresh water adaptation of the rainbow trout whilst the pink salmon is euryhaline and subject to considerable variations in ambient calcium concentrations. Puffer fish is adapted to and maintained in sea water which may also explain the presence of calcitonin gene expression in gill cells.

Calcitonin in the inter-renal tissue may also have a paracrine and/or autocrine action, although its functions in teleost fish kidney are not clear and in mammals it may have both hypo- and hypercalciuric actions (Costanzo \& Windhager 1992). Inter-renal tissue is made up of haemopoietic, lymphoid, chromaffin and nervous elements as well as steroidogenic cells. Whilst interactions between factors within the adrenal have been investigated in mammals (Mazzocchi et al. 1998), little is known of such potential factors and their paracrine effects in lower vertebrates. There are, however, strong possibilities that, as in other tissues, calcitonin could have local controlling actions on the functions of both kidney tubule epithelial cells and on other cells of the inter-renal tissue.
Although the action of calcitonin is fairly well characterised in mammals, little is known about its function in lower vertebrates, particularly with regard to its effect on calcium regulation. Considering all the evidence, it would appear that calcitonin has evolved distinct functions in different lineages which is probably related to lifestyle and calcium availability. Certainly, differences have been found in calcitonin distribution within fish species, depending on whether they are fresh- or salt-water adapted, also age and sex differences have been detected (Oughterson et al. 1995). So, whilst a hypocalcaemic effect has been demonstrated in starved goldfish (Shinozaki \& Mugiya 2000), this may not be the main function in fish. There is evidence to suggest a more prominent role in reproduction (Bjornsson et al. 1989, Norberg et al. 1989) with the distribution results here indicating that it may also act as a potential neuropeptide.

\section{Acknowledgements}

This work was supported by an MRC programme grant (MSC, GE), a Royal Society Joint Project grant $(\mathrm{ESEP} / \mathrm{JP})(\mathrm{MSC}, \mathrm{DMP})$. DMP was funded by FCT, Portugal (BLS 58).

\section{References}

Altschul SF, Madden TL, Schaffer AA, Zhang J, Zhang Z, Miller W \& Lipman DJ 1997 Gapped BLAST and PSI-BLAST, a new generation of protein database search programs. Nucleic Acids Research 25 3389-3402.

Amara SG, Jonas V, Rosenfeld MG, Ong ES \& Evans RM 1982 Alternative RNA processing in calcitonin gene expression generates mRNAs encoding different polypeptide products. Nature $298240-244$.

Ausbel FM, Brent R, Kingston RE, Moore DD, Seidman JG, Smith JA \& Struhl K 1991 Current Protocols in Molecular Biology. New York, Chichester, Brisbane, Toronto, Singapore: J Wiley and Sons.

Bairoch A \& Apweiler R 2000 The SWISS-PROT protein sequence database and its supplement TrEMBL in 2000. Nucleic Acids Research 28 45-48.

Barlet JP, Gaumet N, Coxam V \& Davicco M J 1998 Calcitonin and stanniocalcin: particular aspects of the endocrine regulation of calcium metabolism in fish and mammals. Annales d'Endocrinologie $59281-290$

Bjornsson BTh, Maux C, Forlin L \& Deftos LJ 1987 The involvement of calcitonin in the reproductive physiology of the rainbow trout. Fournal of Endocrinology 108 17-23.

Bjornsson BT, Young G, Lin RJ, Deftos LJ \& Bern HA 1989 Smoltification and seawater adaptation in coho salmon Oncorhynchus kisutch, plasma calcium regulation, osmoregulation, and calcitonin. General and Comparative Endocrinology 74 346-354. 
Bonfield JK \& Staden R 1996 Experiment files and their application during large-scale sequencing projects. DNA Sequence 6 109-117.

Bonfield JK, Smith K \& Staden R 1995 A new DNA sequence assembly program. Nucleic Acids Research 23 4992-4999.

Bouchireb N, Grützner F, Haaf T, Stephens RJ, Elgar G, Green AJ \& Clark MS 2001 Comparative mapping of the human 9q34 region in Fugu rubripes. Cytogenetics and Cell Genetics In Press.

Brenner S, Elgar G, Sandford R, Macrae A, Venkatesh B \& Aparicio S 1993 Characterisation of the pufferfish (Fugu) genome as a compact model vertebrate genome. Nature 366 265-268.

Butkus A, Roche PJ, Fernley RT, Haralambidis J, Penschow JD, Ryan GB, Trahair JF, Tregear GW \& Coghlan JP 1987 Purification and cloning of a corpuscles of Stannius protein from Anguilla australis. Molecular and Cellular Endocrinology 54 123-133.

Buznikov GA 1984 The action of neurotransmitters and related substances on early embryogenesis. Pharmacology and Therapeutics $\mathbf{2 5}$ 23-59.

Costanzo LS 1992 Renal tubular transport of calcium. In Handbook of Physiology, section 8, Renal Physiology, vol II, pp 1759-1783. Eds EE Windhanger \& CG Dacke. Bethesda: American Physiological Society.

Dacke CG 1979 Calcium regulating hormones. In Calcium Regulation in Sub-Mammalian Vertebrates, pp 41-72. London: Academic Press.

Felsenstein J 1981 Evolutionary trees from DNA sequences: a maximum likelihood approach. Fournal of Molecular Evolution 17 368-376.

Flanagan JA, Power DM, Bendell LA, Guerreiro PM, Fuentes J, Clark MS, Canario AVM, Danks JA, Brown BL \& Ingleton PM 2000 Cloning of the cDNA for sea bream Sparus aurata parathyroid hormone-related protein. General and Comparative Endocrinology 118 373-382.

Fouchereau-Peron M, Arlot-Bonnemains Y, Maubras L, Milhaud G \& Moukhtar MS 1990 Calcitonin variations in male and female trout, Salmo gairdneri, during the annual cycle. General and Comparative Endocrinology 78 159-163.

Funakoshi K, Abe T \& Kishida R 1995 Trigeminal, vagal and spinal projections of supramedullary cells in the puffer fish Takifugu niphobles. Fournal of Comparative Neurology 358 552-562.

Funakoshi K, Abe T \& Kishida R 1996 The spinal synpathetic preganglionic cell column in the puffer fish, Takifugu niphobles. Cell and Tissue Research 284 111-116.

Galtier N, Gouy M \& Gautier C 1996 SEAVIEW and PHYLO_WIN, two graphic tools for sequence alignment and molecular phylogeny. Computer Applications in the Biosciences 12 543-548.

Guerreiro PM, Fuentes J, Power DM, Ingleton PM, Flik G \& Canario AVM 2001 Parathyroid hormone-related protein: a calcium regulatory factor in sea bream Sparus aurata larvae. American Fournal of Physiology 281 855-860.

Higgins DG, Bleasby AJ \& Fuchs R 1991 CLUSTAL V, improved software for multiple sequence alignment. Computer Applications in the Biosciences 8 189-191.

Hilton JM, Mitchelhill KI, Pozvek G, Dowton M, Quiza M \& Sexton PM 1998 Purification of calcitonin-like peptides from rat brain and pituitary. Endocrinology 139 982-992.

Inoue A, Shikano M, Komatsu Y, Obata J, Ochiai J, Nishide H, Ito N, Nagao H, Kondo K, Tunemoto D et al. 1991 Structure/activity relationship of eel calcitonin. A study using a newly devised method for designing analogs. European fournal of Biochemistry 201 607-614.

Jansz H, Martial K, Zandberg J, Milhaud G, Benson AA, Julienne A, Moukhtar MS \& Cressent M 1996 Identification of a new calcitonin gene in the salmon Oncorhynchus gorbuscha. PNAS 93 12344-12348.

Jonas V, Lin CR, Kawashima E, Semon D, Swanson LW, Mermod JJ, Evans RM \& Rosenfeld MG 1985 Alternative RNA processing events in human calcitonin/calcitonin gene-related peptide gene expression. PNAS 82 1994-1998.

Kraicer J, Herlant M \& Duclos P 1967 Changes in adenohyphyseal cytology and nucleic acid content in the rat 32 days after bilateral adrenalectomy and the chronic injection of cortisol. Canadian Journal of Physiology and Pharmacology 45 441-446.

Lasmoles F, Jullienne A, Day F, Minvielle S, Milhaud G \& Moukhtar MS 1985 Elucidation of the nucleotide sequence of chicken calcitonin mRNA, direct evidence for the expression of a lower vertebrate calcitonin-like gene in man and rat. $E M B O$ Journal 4 2603-2607.

Martial K, Maubras L, Taboulet J, Jullienne A, Berry M, Milhaud G, Benson AA, Moukhtar MS \& Cressent M 1994 The calcitonin gene is expressed in salmon gills. PNAS 91 4912-4914.

Mazzocchi G, Gottardo G \& Nussdorfer GG 1998 Paracrine control of steroid hormone secretion by chromaffin cells in the adrenal gland of lower vertebrates. Histology and Histopathology 13 209-220.

Milhaud G, Rankin JC, Bolis L \& Benson AA 1977 Calcitonin: its hormonal action on the gill. PNAS 74 4693-4696.

Miniveille S, Cressent M, Delehaye MC, Segond N, Milhaud G, Jullienne A, Moukhtar MS \& Lasmoles F 1987 Sequence and expression of the chicken calcitonin gene. FEBS Letters 223 63-68.

Norberg B, Bjornsson BT, Brown CL, Wichardt UP, Deftos LJ \& Haux C 1989 Changes in plasma vitellogenin, sex steroids, calcitonin, and thyroid hormones related to sexual maturation in female brown trout Salmo trutta. General and Comparative Endocrinology 75 316-326.

Olsen GJ, Overbeek R, Larsen N, Marsh TL, McCaughey MJ, Maciukenas MA, Kuan WM, Macke TL, Xing Y \& Woese CR 1992 The Ribosomal Database Project. Nucleic Acids Research 20 Suppl 2199-2200.

Oughterson SM, Munoz-Chapuli R, De Andres V, Lawson R, Heath S \& Davies DH 1995 The effects of calcitonin on serum calcium levels in immature brown trout, Salmo trutta. General and Comparative Endocrinology 97 42-48.

Postlethwait JH, Woods IG, Ngo-Hazelett P, Yan YL, Kelly PD, Chu F, Huang H, Hill-Force A \& Talbot WS 2000 Zebrafish comparative genomics and the origins of vertebrate chromosomes. Genome Research 10 1890-1902.

Power DM, Ingleton PM, Flanagan JA, Canario AVM, Danks J, Elgar G \& Clark MS 2000 Genomic structure and expression of parathyroid hormone-related protein gene PTHrP in a teleost, Fugu rubripes. Gene $\mathbf{2 5 0} 67-76$.

Rosenfeld MG, Amara SG, Roos BA, Ong ES \& Evans RM 1981 Altered expression of the calcitonin gene associated with RNA polymorphism. Nature $29063-65$.

Saitou N \& Nei M 1987 The neighbor-joining method, a new method for reconstructing phylogenetic trees. Molecular Biology and Evolution 4 406- 425.

Shah GV, Chien J, Sun YP, Puri S \& Ravindra R 1999 Calcitonin inhibits anterior pituitary cell proliferation in the adult female rats. Endocrinology 140 4281-4291.

Sherwood NM, Krueckl SL \& McRory JE 2000 The origin and function of the pituitary adenylate cyclase-activating polypeptide PACAP/glucagon superfamily. Endocrine Reviewes 21 619-670.

Shinozaki F \& Mugiya Y 2000 Effects of salmon calcitonin on calcium deposition on and release from calcified tissues in fed and starved goldfish Carassius auratus. Fisheries Science 66 695-700.

Suzuki N, Ueda K, Sakamoto H \& Sasyama Y 1999 Fish calcitonin genes: primitive bony fish genes have been conserved in some lower vertebrates. General and Comparative Endocrinology 113 359-373.

Takei Y, Takahashi A, Watanabe TX, Nakajima K, Sasayama Y, Suzuki N \& Oguro C 1991 New calcitonin isolated from the ray, Dasyatis akajei. The Biological Bulletin 180 485-488. 
Taylor TG, Balderstone O \& Lewis PE 1975 Changes in the concentration of calcitonin in the plasma of chick embryos during incubation. Fournal of Endocrinology 66 363-368.

Tsai SC, Lu CC, Chen JJ, Chiao YC, Wang SW, Hwang JJ \& Wang PS 1999 Inhibition of salmon calcitonin on secretion of progesterone and Gn-RH-stimulated pituitary luteinizing hormone. American Fournal of Physiology, Endocrinology and Metabolism 277 E49-E55.

Uchiyama M, Yoshihara M, Murakami T \& Oguro C 1981 Calcitonin content in the ultimobranchial gland of the snake, Elaphe climacophora, comparison of adults, young, and hatchlings. General and Comparative Endocrinology 43 259-261.

Venkatesh B, Tay BH, Elgar G \& Brenner S 1996 Isolation, characterization and evolution of nine pufferfish Fugu rubripes actin genes. Fournal of Molecular Biology 259 655-665.
Wagner GF, Jaworski EM \& Radman DP 1997 Salmon calcitonin inhibits body $\mathrm{Ca}^{2+}$ uptake in young rainbow trout. Fournal of Endocrinology $155459-465$.

Wisneski LA 1990 Salmon calcitonin in the acute management of hypercalcemia. Calcified Tissue International 46 S26-S30.

Yoshida A, Kaiya H, Takei Y, Watanabe TX, Nakajima K, Suzuki N \& Sasayama Y 1997 Primary structure and bioactivity of bullfrog calcitonin. General and Comparative Endocrinology 107 $147-152$.

Received 23 October 2001 Accepted 21 December 2001 